Pacific Journal of Mathematics

MATRIX SUMMABILITY OF A CLASS OF DERIVED FOURIER 


\section{MATRIX SUMMABILITY OF A CLASS OF DERIVED FOURIER SERIES}

\section{ARIBINDi Satyanarayan RaO}

Let $f$ be $L$-integrable and periodic with period $2 \pi$, and let

$$
\sum_{n=1}^{\infty} n\left(b_{n} \cos n x-a_{n} \sin n x\right)
$$

be the derived Fourier series of the function $f$ with partial sums $s_{n}^{\prime}(x)$. We write

$$
\begin{aligned}
\psi_{x}(t) & =f(x+t)-f(x-t) ; \\
g_{x}(t) & =\frac{\psi_{x}(t)}{4 \sin t / 2} .
\end{aligned}
$$

In this paper, the following theorems are established.

Theorem 1. Let $A=\left(a_{m n}\right)$ be a regular infinite matrix of real numbers. Then, for every $x \in[-\pi, \pi]$ for which $g_{x}(t)$ is of bounded variation on $[0, \pi]$,

$$
\lim _{m \rightarrow \infty} \sum_{n=1}^{\infty} a_{m n} s_{n}^{\prime}(x)=g_{x}(0+)
$$

if and only if

$$
\lim _{m \rightarrow \infty} \sum_{n=1}^{\infty} a_{m n} \sin (n+1 / 2) t=0 \text { for all } t \in[0, \pi] \text {. }
$$

Theorem 2. Let $A=\left(a_{m n}\right)$ be an almost regular infinite matrix of real numbers. Then, for each $x \in[-\pi, \pi]$ for which $g_{x}(t)$ is of bounded variation on $[0, \pi]$,

$$
\lim _{p \rightarrow \infty} \frac{1}{p} \sum_{j=0}^{p-1} t_{m+j}^{\prime}(x)=g_{x}(0+)
$$

uniformly in $m$ if and only if

$$
\lim _{p \rightarrow \infty} \frac{1}{p} \sum_{j=0}^{p-1} \sum_{n=1}^{\infty} a_{m+j, n} \sin (n+1 / 2) t=0 \text { for all } t \in[0, \pi],
$$

uniformly in $m$, where

$$
t_{m}^{\prime}(x)=\sum_{n=1}^{\infty} a_{m n} s_{n}^{\prime}(x)
$$

2. Proof of Theorem 1. We have

$$
\begin{aligned}
s_{n}^{\prime}(x) & =\frac{1}{\pi} \int_{0}^{\pi} \psi_{x}(t)\left(\sum_{k=1}^{n} k \sin k t\right) d t \\
& =-\frac{1}{\pi} \int_{0}^{\pi} \psi_{x}(t) \frac{d}{d t}\left[\frac{\sin (n+1 / 2) t}{2 \sin t / 2}\right] d t \\
& =I_{n}+\frac{2}{\pi} \int_{0}^{\pi} \sin (n+1 / 2) t d g_{x}(t),
\end{aligned}
$$


where

$$
\begin{gathered}
I_{n}=\frac{1}{\pi} \int_{0}^{\pi} g_{x}(t) \frac{\sin (n+1 / 2) t}{\tan t / 2} d t \\
\sum_{n=1}^{\infty} a_{m n} s_{n}^{\prime}(x)=\sum_{n=1}^{\infty} a_{m n} I_{n}+\frac{2}{\pi} \int_{0}^{\pi} L_{m}(t) d g_{x}(t),
\end{gathered}
$$

where

$$
L_{m}(t)=\sum_{n=1}^{\infty} a_{m n} \sin (n+1 / 2) t .
$$

Since $g_{x}(t)$ is of bounded variation on $[0, \pi]$ and tends to $g_{x}(0+)$ as $t \rightarrow 0, g_{x}(t) \cos t / 2$ has the same properties; so, by Jordan's convergence criterion for Fourier series,

$$
I_{n} \longrightarrow g_{x}(0+) \text { as } n \longrightarrow \infty \text {. }
$$

By the regularity of our method of summation, it follows that

$$
\lim _{m \rightarrow \infty} \sum_{n=1}^{\infty} a_{m n} I_{n}=g_{x}(0+) \text {. }
$$

Hence we have to show that, if (1.3) holds, then

$$
\lim _{m \rightarrow \infty} \int_{0}^{\pi} L_{m}(t) d g_{x}(t)=0
$$

and conversely.

By a theorem on the weak convergence of sequences in the Banach space of all continuous functions defined on a finite closed interval (see Banach [1], pp. 134-135), it follows that (2.7) holds if and only if

$$
\left|L_{m}(t)\right| \leqq K \text { for all } m \text { and for all } t \in[0, \pi]
$$

and (1.3) holds, where $K$ is a constant.

Since (2.8) is automatically satisfied by one of the regularity conditions on $A$, it follows that (2.7) holds if and only if (1.3) holds. Thus the proof of the theorem is completed.

REMARKs. (a) We observe that, for each $g_{0}(t)$ of bounded variation on $[0, \pi]$, we have a corresponding odd function $f \in L[-\pi, \pi]$ given by

$$
f(t)=1 / 2 \psi_{0}(t)=2 g_{0}(t) \cdot \sin t / 2 \quad \text { on } \quad[0, \pi] .
$$

(b) If $a_{m n}=1 / m$ for $n \leqq m$ and zero for $n>m$, then the condition (1.3) is obviously satisfied. 
3. Note. A bounded sequence $\left\{s_{n}\right\}$ is said to be almost convergent to $s$ if

$$
\lim _{p \rightarrow \infty} \frac{s_{n}+s_{n+1}+\cdots+s_{n+p-1}}{p}=s
$$

uniformly in $n$ (see Lorentz [4]).

It is easy to see that a convergent sequence is almost convergent and the limits are the same.

Let $A=\left(a_{m n}\right)$ be an infinite matrix of real numbers. A bounded sequence $\left\{s_{n}\right\}$ is said to be almost $A$-summable to $s$ if the $A$-transform of $\left\{s_{n}\right\}$ is almost convergent to $s$, and the matrix $A$ is said to be almost regular if $s_{n} \rightarrow s$ implies that the sequence $\left\{t_{m}\right\}$ of the $A$-transforms of $\left\{s_{n}\right\}$ is almost convergent to $s$.

Necessary and sufficient conditions for the matrix $A$ to be almost regular are as follows (see King [3]):

(3.2) $\sup _{p \geqq 1}\left(\sum_{n=1}^{\infty} \frac{1}{p}\left|\sum_{j=m}^{m+p-1} a_{j n}\right|\right)<M(m=1,2, \cdots ; M=a \quad$ constant $)$;

$$
\lim _{p \rightarrow \infty} \frac{1}{p} \sum_{j=m}^{m+p-1} a_{j n}=0 \quad \text { uniformly in } m \quad(n=1,2, \cdots) \text {; }
$$

$$
\lim _{p \rightarrow \infty} \frac{1}{p} \sum_{j=m}^{m+p-1} \sum_{n=1}^{\infty} a_{j n}=1 \quad \text { uniformly in } m .
$$

We establish the following

THEOREM 2. Let $A=\left(a_{m n}\right)$ be an almost regular infinite matrix of real numbers. Then, for every $x \in[-\pi, \pi]$ for which $g_{x}(t)$ is of bounded variation on $[0, \pi]$,

$$
\lim _{p \rightarrow \infty} \frac{1}{p} \sum_{j=0}^{p-1} t_{m+j}^{\prime}(x)=g_{x}(0+)
$$

uniformly in $m$ if and only if

$$
\lim _{p \rightarrow \infty} \frac{1}{p} \sum_{j=0}^{p-1} \sum_{n=1}^{\infty} a_{m+j, n} \sin (n+1 / 2) t=0 \text { for all } t \in[0, \pi]
$$

uniformly in $m$, where

$$
t_{m}^{\prime}(x)=\sum_{n=1}^{\infty} a_{m n} s_{n}^{\prime}(x)
$$

$s_{n}^{\prime}(x)$ being the partial sum of the derived Fourier series (1.1) of $f$.

Proof. We have, by (2.1), 


$$
\begin{aligned}
\text { (3.7) } & =\frac{1}{p} \sum_{j=0}^{p-1} \sum_{n=1}^{\infty} a_{m+j, n} I_{n}+\frac{2}{\pi} \int_{0}^{\pi}\left[\frac{1}{p} \sum_{j=0}^{p-1} \sum_{n=1}^{\infty} a_{m+j, n} \sin (n+1 / 2) t\right] d g_{x}(t) \\
& =J_{1}+J_{2},
\end{aligned}
$$

say.

By (2.5), $A$ being almost regular,

$$
J_{1} \longrightarrow g_{x}(0+) \text { uniformly in } m \text { as } p \longrightarrow \infty \text {. }
$$

So we have to show that (3.6) holds if and only if

$$
J_{2} \longrightarrow 0 \text { uniformly in } m \text { as } p \longrightarrow \infty \text {. }
$$

Now,

$$
\begin{aligned}
& \left|\frac{1}{p} \sum_{j=0}^{p-1} \sum_{n=1}^{\infty} a_{m+j, n} \sin (n+1 / 2) t\right| \\
= & \left|\frac{1}{p} \sum_{n=1}^{\infty} \sin (n+1 / 2) t \sum_{j=0}^{p-1} a_{m+j, n}\right| \\
\leqq & \frac{1}{p} \sum_{n=1}^{\infty}|\sin (n+1 / 2) t| \cdot\left|\sum_{j=0}^{p-1} a_{m+j, n}\right| \\
\leqq & \sum_{n=1}^{\infty} \frac{1}{p}\left|\sum_{j=0}^{p-1} a_{m+j, n}\right|<M \text { for all } p \text { and } m, \text { by (3.2). }
\end{aligned}
$$

Hence the remainder of the proof is similar to that of Theorem 1.

I thank Professor A. Meir for his useful comments in the preparation of this paper.

\section{REFERENCES}

1. S. Banach, Théorie des operations linéaires, (Warsaw, 1932).

2. G. H. Hardy, Divergent series, (Oxford, 1949).

3. J. P. King, Almost summable sequences, Proc. Amer. Math. Soc., 17 (1966), 1219-1225.

4. G. G. Lorentz, A contribution to the theory of divergent sequences, Acta Mathematica, 80 (1948), 167-190.

5. O. P. Varshney, On the matrix summability of the derived Fourier series, Bolletino della Unione Matematica Italiana (3), 16 (1961), 379-382.

6. A. Zygmund, Trigonometric series, second edition, New York, 1952.

Received May 26, 1972.

UNIVERSITY OF ALBERTA 


\section{PACIFIC JOURNAL OF MATHEMATICS}

\section{EDITORS}

RICHARD ARENS (Managing Editor)

University of California

Los Angeles, California 90024

\author{
R. A. Beaumont \\ University of Washington \\ Seattle, Washington 98105
}

J. Dugundu*

Department of Mathematics

University of Southern California

Los Angeles, California 90007

D. Gilbarg and J. Milgram

Stanford University

Stanford, California 94305

\section{ASSOCIATE EDITORS}
E. F. BECKENBACH
B. H. NeumanN
F. WOLF
K. YosHIDA

\section{SUPPORTING INSTITUTIONS}

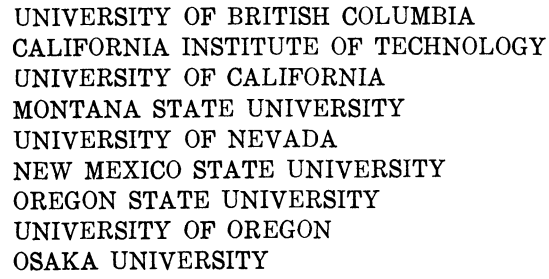

UNIVERSITY OF BRITISH COLUMBIA CALIFORNIA INSTITUTE OF TECHNOLOGY

UNIVERSITY OF CALIFORNIA

MONTANA STATE UNIVERSITY

UNIVERSITY OF NEVADA

NEW MEXICO STATE UNIVERSITY

OREGON STATE UNIVERSITY

UNIVERSITY OF OREGON

OSAKA UNIVERSITY

\author{
UNIVERSITY OF SOUTHERN CALIFORNIA \\ STANFORD UNIVERSITY \\ UNIVERSITY OF TOKYO \\ UNIVERSITY OF UTAH \\ WASHINGTON STATE UNIVERSITY \\ UNIVERSITY OF WASHINGTON \\ * * * \\ AMERICAN MATHEMATICAL SOCIETY \\ NAVAL WEAPONS CENTER
}

The Supporting Institutions listed above contribute to the cost of publication of this Journal, but they are not owners or publishers and have no responsibility for its content or policies.

Mathematical papers intended for publication in the Pacific Journal of Mathematics should be in typed form or offset-reproduced, (not dittoed), double spaced with large margins. Underline Greek letters in red, German in green, and script in blue. The first paragraph or two must be capable of being used separately as a synopsis of the entire paper. Items of the bibliography should not be cited there unless absolutely necessary, in which case they must be identified by author and Journal, rather than by item number. Manuscripts, in duplicate if possible, may be sent to any one of the four editors. Please classify according to the scheme of Math. Rev. Index to Vol. 39. All other communications to the editors should be addressed to the managing editor, or Elaine Barth, University of California, Los Angeles, California, 90024.

50 reprints are provided free for each article; additional copies may be obtained at cost in multiples of 50 .

The Pacific Journal of Mathematics is issued monthly as of January 1966. Regular subscription rate: $\$ 48.00$ a year (6 Vols., 12 issues). Special rate: $\$ 24.00$ a year to individual members of supporting institutions.

Subscriptions, orders for back numbers, and changes of address should be sent to Pacific Journal of Mathematics, 103 Highland Boulevard, Berkeley, California, 94708.

PUBLISHED BY PACIFIC JOURNAL OF MATHEMATICS, A NON-PROFIT CORPORATION

Printed at Kokusai Bunken Insatsusha (International Academic Printing Co., Ltd.), 270, 3-chome Totsuka-cho. Shinjuku-ku, Tokyo 160, Japan.

* C. R. DePrima California Institute of Technology, Pasadena, CA 91109, will replace J. Dugundji until August 1974.

Copyright (C) 1973 by

Pacific Journal of Mathematics

All Rights Reserved 


\section{Pacific Journal of Mathematics}

Vol. 48, No. $2 \quad$ April, 1973

Mir Maswood Ali, Content of the frustum of a simplex................

Mieczyslaw Altman, Contractors, approximate identities and factorization

in Banach algebras ................................ 323

Charles Francis Amelin, A numerical range for two linear operators ...... 335

John Robert Baxter and Rafael Van Severen Chacon, Nonlinear functionals

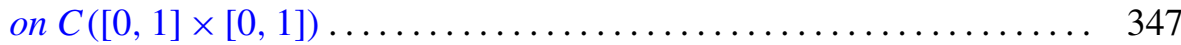

Stephen Dale Bronn, Cotorsion theories....................... 355

Peter A. Fowler, Capacity theory in Banach spaces............... 365

Jerome A. Goldstein, Groups of isometries on Orlicz spaces ........... 387

Kenneth R. Goodearl, Idealizers and nonsingular rings . ............ 395

Robert L. Griess, Jr., Automorphisms of extra special groups and

nonvanishing degree 2 cohomology ..................... 403

Paul M. Krajkiewicz, The Picard theorem for multianalytic functions . . . . 423

Peter A. McCoy, Value distribution of linear combinations of axisymmetric harmonic polynomials and their derivatives ...................

A. P. Morse and Donald Chesley Pfaff, Separative relations for

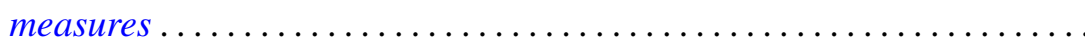

Albert David Polimeni, Groups in which $\operatorname{Aut}(G)$ is transitive on the

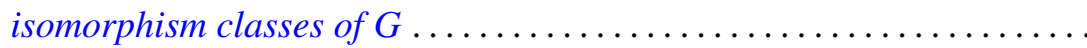

Aribindi Satyanarayan Rao, Matrix summability of a class of derived

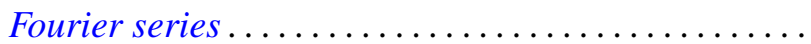

Thomas Jay Sanders, Shape groups and products

Ruth Silverman, Decomposition of plane convex sets. II. Sets associated

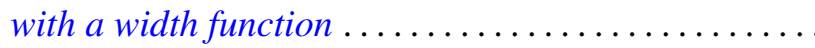

Richard Snay, Decompositions of $E^{3}$ into points and countably many flexible dendrites.............................

John Griggs Thompson, Nonsolvable finite groups all of whose local subgroups are solvable, IV ...

Robert E. Waterman, Invariant subspaces, similarity and isometric equivalence of certain commuting operators in $L_{p} \ldots$

James Chin-Sze Wong, An ergodic property of locally compact amenable

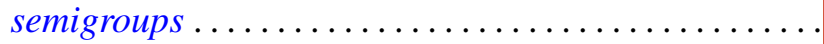

Julius Martin Zelmanowitz, Orders in simple Artinian rings are strongly equivalent to matrix rings ....................... 